\title{
Palm kernel cake (Elaeis guineensis) in the diet of collared peccary (Pecari tajacu) raised in captivity in Brazilian Amazon (Partial results)
}

\author{
Natália Inagaki de Albuquerque ${ }^{1 \dagger}$, Priscila Reis Kahwage ${ }^{1}$, Maria Hilma Soares Sodré ${ }^{\text {, }}$ \\ José Aparecido Moreira², Hilma Lucia Tavares Dias² and Diva Anélie Guimarães ${ }^{2}$ \\ ${ }^{1}$ Embrapa Amazônia Oriental Tv. Enéas Pinheiro s/n, Bairro do Marco, Cep: 66.095-100, Belém-Pará-Brasil; ${ }^{2}$ Universidade Federal do Pará - Instituto de Ciências
} Biológicas - Laboratório de Reprodução Animal, Belém-Pará-Brasil; ${ }^{3}$ Centro de Energia Nuclear na Agricultura - USP, Piracicaba-São Paulo-Brasil

Introduction

Wild animals have been raised in captivity for commercial purposes in Latin America and the Caribbean. One is the collared peccary (Pecari tajacu), that is a good source of protein for Amazonian inhabitants. However, whilst this artiodactyla mammal is well adapted to a captive breeding system the live weight production cost is high. Palm kernel cake Elaeis guineensis, by-product of the extraction of the palm oil, has been used as an alternative diet to partially replace commercial ration ingredients of some animal diets. Its chemical composition means it can be used used in non-ruminants diets. This work evaluated the effects of a partial substitution of the corn (Triticum aestivum) by palm kernel cake in collared peccary diets.

\section{Material and methods}

This study was conducted on the experimental farm Senador Alvaro Adolfo of Embrapa (Belém, Pará, Brazil, $01^{\circ} 24^{\prime} \mathrm{S} ; 48^{\circ} 20^{\prime} \mathrm{W}$ ). The climate is equatorial with an average annual temperature of $27^{\circ} \mathrm{C}$, and an average relative humidity of $80 \%$. The experiment was conducted to evaluate the performance of 24 finisher phase collared peccary fed diet with different replacement levels of palm kernel cake. The experimental design was completely randomized blocks with four treatments (TA: $22.5 \%$; TB: $15 \%$; TC: $7.5 \%$ and TD: $0 \%$ ) and three repetitions. Each experimental period lasted 45 days for adaptation and 60 days for data collection. The animals were enclosed in 12 small paddocks of $12 \mathrm{~m}{ }^{2}$ ( 2 animals per paddock), maintained under natural lighting conditions and temperatures ranging from $22^{\circ}$ to $32^{\circ} \mathrm{C}$. Water was supplied $a d$ libtum. The animals were weight in the beginning and in the end of the experimental period.

\section{Results}

There was an increase in live weight $(\mathrm{Kg})$ relevant to increased levels of palm cake kernel in the diet: TA: 0.05; TB: $0.05 ; \mathrm{TC}: 0.04$ and TD: 0.01 . The ration consumption was: TA: $437.68 \mathrm{~g}$; TB: $436.25 \mathrm{~g}$; TC: $436.54 \mathrm{~g}$ and TD: $440.27 \mathrm{~g}$.

\section{Conclusions}

In conclusion, the results at this moment show that feeding with palm kernel cake at the finisher phase of collared peccary seems to increase the live weight. The palm cake could be increased in the diet of this species and then decreases the cost of production. The next stage of this research will be to conduct an experiment with more than 16 animals and two repetitions.

\section{Acknowledgements}

This study was financed by FAPESPA (SEDECT-PARÁ).

\footnotetext{
†E-mail: natalia@cpatu.embrapa.br
} 